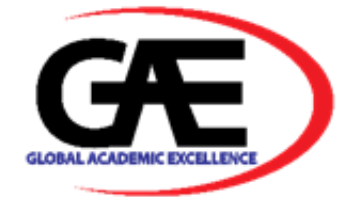

\title{
THE ROLE OF MARTIAL COURT IN THE PERSPECTIVE OF LAW ENFORCEMENT IN INDONESIA
}

\author{
Mahfutt $^{1 *}$, Khairil Anwar ${ }^{2}$, Billi Belladona Matindas ${ }^{3}$ \\ 1 Universiti of Jayabaya, Indonesia \\ Email: mahfutt55@yahoo.com \\ 2 Universiti of Jayabaya, Indonesia \\ Email: khairilanwar2238@yahoo.com \\ 3 Universiti of Jayabaya, Indonesia \\ Email: billymatindas@yahoo.com \\ * Corresponding Author
}

\section{Article Info:}

\section{Article history:}

Received date: 01.08 .2020

Revised date: 15.08 .2020

Accepted date: 10.01.2021

Published date: 05.03.2021

\section{To cite this document:}

Mahfutt., Anwar, K., \& Matindas, B. B. (2021). The Role Of Martial Court In The Perspective Of Law Enforcement In Indonesia. International Journal of Law, Government and Communication, 6 (22), 66-73.

DOI: $10.35631 /$ IJLGC.622006.

This work is licensed under $\underline{\text { CC BY } 4.0}$

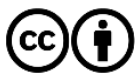

\begin{abstract}
:
The position of the Military Court is a body that executes the judicial power in the circle of the Indonesian National Armed Forces to enforce the law and justice with due observance of the interest in the state defense and safety. The Military Court is authorized to try the crimes committed by someone who when committing such crime is a soldier of the Indonesian National Armed Forces, a member of a group or office or body or equal to a soldier pursuant to the Law and someone is not included in the said group as set forth in the Law Number 31 of 1997 on Military Court. Following the reform of 1988, the existence of the Military Court is developed by some activists and the public that observe the Military Court, insisting the Parliament of the Republic of Indonesia to revise Law Number 31 of 1997 on Military Court, with the focus point for a soldier of the Indonesian National Armed Forces who commits a general crime to be tried in the General Court with the reason that the Military Court practice is closed in nature, and another reason is the equalization of rights before the law. The method used in this research is the normative law research that is carried out to obtain the necessary data relating to the problem. The data used is secondary data consisting of primary law materials, secondary law materials, and tertiary law materials. In addition, primary data is also used as the support of the secondary data law materials. The data is analyzed by the qualitative juridical analysis method. The results of the research show that the Military Court is one of the mechanisms that are always tried to be maintained. The outcome from the research discovers that the role of the Martial Court in Indonesia remains effective, fair, and democratic to this date realistically marked by fair punishment within the jurisdiction offended, which corresponds to the need of TNI institution in the aspects of Culture, Benefit, Assurance, and Fairness. It is recommended that the RI Government continuously develop and improve the same by
\end{abstract}




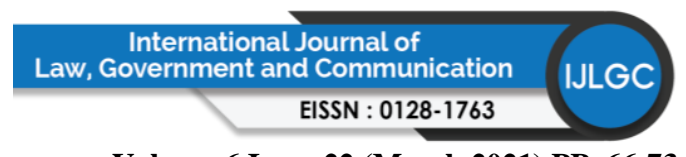

Volume 6 Issue 22 (March 2021) PP. 66-73

DOI 10.35631/IJLGC.622006

maintaining the role of the Martial Court in punishing criminal offenses committed by military members on the Martial Court system currently in force.

Keywords:

Military Court, Independ, Reinforcement of Martial Court

\section{Introduction}

Indonesia's judicial system is made up of all of the components of Indonesia's judiciary, the parties in the judiciary process, hierarchy of the judicial institution and procedural aspects that are so related that legal justice is served. The criminal law system operates to enforce the criminal law, to punish offenders and to guarantee law enforcement. Criminal justice in Indonesia is organized by the criminal law agencies, which are the Police, the Prosecutors, the Courts and the Panitentiaries. These agencies communicate with one another when handling cases. Juridically, the existence of military court is set out in Article 24 paragraph (2) of the 1945 Constitution, which states judicial power is exercised by the Supreme Court and the judicial bodies below it within courts of general jurisdiction, religious courts, military courts, administrative courts and by the Constitutional Court. Only few of Indonesian people pay their attention to the development of the military law (Eva Achjani Zufa \& Indriyanto Seno Adji, 2011).

This is made possible as people think that military law development is just for the military circle to have knowledge of. In fact, there is nothing wrong with this, but at the same time it is not always right. The military law of a country is a sub-system of the law of that country, because military is part of a society or a country that performs special duty, i.e., defending the state and country using weapons or, in other words, the main duty is combating. The persons involved in the military are educated, trained and prepared for combat. They are therefore provided with specific norms or principles. Many offences under the military justice system have no equivalent when they are compared with civil law because it is subject in form to the military's professional code of ethic. Therefore, the intended purpose is not only to provide justice to the accused or the other victims, but also to maintain the effective funtion and position of the military in a democratic society.

Civil courts can be administered to provide justice to military members, but this practice cannot accommodate the manners in which the military implements its rules. Military court has no qualification to perform administrative professional aspect of the military court. Civil courts have no adequate knowledge of how an incident could affect the morale or discipline in the military. Civil courts also do not have the expertise in figuring out how something can affect the making of a military decision. A legal obligation can have unexpected adverse effects in any situation. Kelsen (2011), in his book general theory of law and state, views that law as a social order can be stated to be fair if it can satisfactorily arrange the acts of human beings so that happiness can be found in it.

The Indonesian National Armed Forces (TNI) is part of a law society that plays the role of supporting the formation of law in the military circle. Legal awareness within the TNI cannot be expected to grow if the TNI members as the supporter of the legal culture do not give contribution by always observing all rules in force and behaving and acting on the basis of Copyright (C) GLOBAL ACADEMIC EXCELLENCE (M) SDN BHD - All rights reserved 


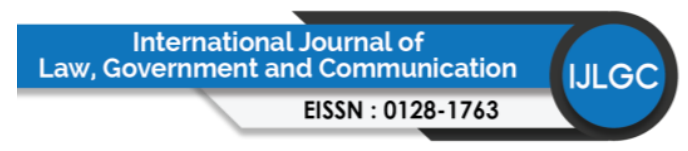

Volume 6 Issue 22 (March 2021) PP. 66-73

DOI 10.35631/IJLGC.622006

the law. Understanding legal awareness should always be fostered in order to develop a lawabiding behavior in each TNI individual. Raising the TNI soldier's legal awareness and law enforcement should be priority in the TNI personnel development policy, because lack of legal understanding would lead to the violation of the law in addition to other internal and external influences. TNI is an organization which serves as a defense tool for the Unitary State of the Republic of Indonesia, implements the State's defense policies to uphold the sovereignty of the State, maintains the integrity of the territory, protects the safety of the country, conducts military operations in war and other operations, and actively involves in the keeping of regional and international peace.

The role of Indonesian Martial Court Indonesia is defined in Article 9 of Law Number 31 of 1997 on Martial Court stating that the Martial Court shall punish the criminal offenses committed by Indonesian National Soldier (TNI). Martial Court System in Malaysia does not distinguish the criminal offender. Therefore, civil person or military member involved in the general criminal offense is punished by civil criminal court. The independence of this judicial body has been confirmed in the Federal Constitution. The issues relating to the official affairs and disciplinary violation for members of Malaysia Armed Forces is defined in Law of Malaysia Act 77, also called Armed Forces Act, 1972 and this specifically applies to the members of Armed Forces. The condition of the court in Malaysia, with separation between general criminal offenses from military (civil effeteness committed by military members), will be punished by General/Civil Court, meanwhile offense relating to the duty and or military office will be punished by the martial court (Marcus Priyo Gunarto, November).

With respect to Military Court after the 1998 reform, some community elements raised an issue on the Existence of Military Court Independence where a TNI Soldier who has committed a General offence may be brought to a Court of General Jurisdiction. Observing the development of the law, especially the development of the military law, it is important to continuingly build and develop the authority of the military justice system. For this reason, the writer would like to look into the "Existence of Military Court Independence as Viewed from Law Enforcement Aspect in Indonesia.

\section{Purposes and Objectives}

This paper is expected to enrich the treasure of the knowledge of law in general and the existence of Military Court Law in particular. In addition, in accordance with the problem description, the purposes of this paper are particularly as follows:

1. To figure out how the Military Court Law should be continuously built and developed in the Military Justice System in Indonesia in order to provide justice in Indonesia's justice system.

2. To figure out the ideal concept of existence of Military Court Independence in the trial of the TNI soldiers committing a general offence.

\section{Identification of Problem}

The Military Court's existence as part of Indonesia's law enforcement system is continuingly built and developed, but there have recently been certain community elements who wanted to revise the authority of the Military Court particularly the authority to bring to a court of general jurisdiction any TNI soldier who has committed a general offence. The problem in this paper is then described as follows: 


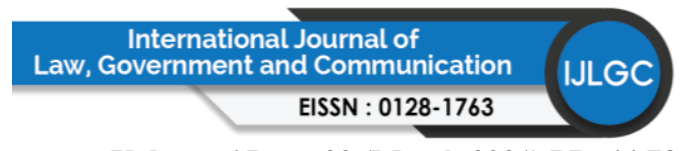

Volume 6 Issue 22 (March 2021) PP. 66-73

DOI 10.35631/IJLGC.622006

1. How the Military Court Law should be continuously built and developed in the Military Justice System in Indonesia?

2. What is the ideal concept of existence of Military Court Independence in the trial of the TNI soldiers who commit a general offence?

\section{Research Method}

The method used in this research is normative legal research, which is aimed to obtain the necessary data in relation to the problem. The data used is secondary data, which is made up of primary, secondary and tertiary law-related materials. Primary data is also used to support the law-related materials of secondary data. Data analysis is done using qualitative juridical analysis (Kamus Besar Bahasa Indonesia, 2012). To describe Indonesia's Military justice system in a more independent trial of general offences committed by TNI soldiers in the future. The research focused on legislations pertinent to law enforcement process in the Martial Court system, especially as to the role of Martial Court in rendering punishment to general criminal offenses or military criminal offenses committed by military members. Based on the focus of the research, the research method applied was normative research or law literature research using the method or means used in the law research on literature references available (Soerjono Soekanto \& Sri Mamudji, 2009).

In coping with the formulating the problem, there is a necessity to review the legislations e.g. Law Number 31 of 1997 on Martial Court and Law Number 39 of 1947 on Military Criminal Code of Procedure (KUHPM), and Law Number 8 of 1981 dated 31 December 1981 on Criminal Code of Procedure

\section{Discussion}

Justice in Indonesia is provided for in Article 24 paragraph (2) of the 1945 Constitution which confirms that judicial authority is exercised by the Supreme Court and the judicial bodies within the five jurisdictions, which are religious court, military court, administrative court and Constitutional Court. Article 9 of the Law Number 31 of 1997 regarding Military Court states that a Court of military jurisdiction adjudicates the offences committed by the Indonesian National Armed Forces (TNI). In performing their heavy and very special duties and obligations, TNI members are educated and trained to observe orders or decisions without objection and to carry out the orders or decisions in efficient and effective manners outside the people, not a caste which stands above the people (Amiroeddin Sjarif, 1983)

Military is characterized by its well organized organization, wearing of uniform, keeping of discipline, and observance of the war laws in force. If these characteristics are not met, the group cannot be called a military, instead it is an armed gang (Moch. Faisal Salam, 1994). SR. Sianturi (2011) provides the definition of military criminal law from justice seeker point of view as the persons who are subject and subjected to certain judicial body. Procedural and substantive military criminal laws are parts of the positive law, applicable to justice seekers in the military court, which determines the grounds for and rules on restrictive and requisite acts and punishable violations. According to Amiroeddin Syarif (1996), military is a person who is educated, trained and prepared for a battle. For this reason they are provided with specific norms and principles and must observe without reserve the specifically defined code of conduct and their performance is closely monitored. The Military rules of law applied to all TNI members, either enlisted man, noncom or officer who commits an act that harm the unit, the general public and the state, closely related to other regulations which are also 


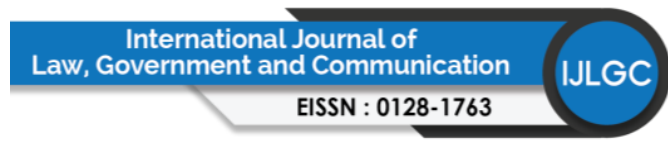

Volume 6 Issue 22 (March 2021) PP. 66-73

DOI 10.35631/IJLGC.622006

applied to the general public, are the Military Criminal Code (KUHPM), the Military Disciplinary Code (KUHDM), the Military Disciplinary Regulation (PDM) and other regulations.

According to Leon Duguit in Zainudin Ali (2008), Law regulates the behavior of the society members, a rule the enforceability of which in certain occasion is observed by a community as a guarantee of common interests and the breach of which will cause a common reaction to the doer. Further, according to Amin in Tiena Masriani Yulies (2004), Law is a set of rules consisting of norms and sanctions, with the purpose to bring order in human interactions.

Law enforcement is an effort to rationally deal with crimes, to satisfy the sense of justice and to be productive. For the purpose of dealing with crimes, there are means which can be used as a reaction to offenders. They are criminal and non-criminal means which can be integrated with one another (Barda Nawawi Arief, 2002). When criminal means are invoked to deal with crimes, it means that criminal law politics will be carried out, i.e., holding an election to achieve appropriate criminal legislation according to the circumstance and situation at a time and in the future. Conceptually, the essence of law enforcement lies in the activities done to harmonize the relationship of values translated in stable and visible principles and the attitude to act as a series of final translations of the values, in order to create, maintain and keep peaceful interaction in life. Therefore, it can be said that law enforcement does not simply mean implementation of laws. Such theory of enforcement as set out above is in line with the law enforcement within the military circle which is part of the military justice subsystem in the adjudication of any military members who commit an offence. Despite this, law enforcement does not merely mean implementation of laws (Soerjono Soekanto, 2005). Besides, law enforcement can guarantee legal certainty, law and order and legal protection in this modern and global era if the dimensions of legal life always maintain compatibility, balance and harmony in the morale of the civilians based upon the actual values in a civilized society.

According to Dini Dewi Heniarti (2017), military justice system consists of driven and operated subsystems, which are investigation system, which is performed by the superior having the authority to impose punishment, military police, and military prosecuting attorney, prosecution/pre-prosecution system, which is performed by military prosecuting attorney and prosecution officer, court hearing system by the military court, and criminal enforcement system by military penitentiary, forming a unit of law enforcement officers with duties to take action against any TNI members who commit an offence. As a process, it is a series of enforcement in the application of the military criminal procedure which consists of inquiry, investigation, arrest, detention, case submission, prosecution, trial and enforcement of criminal judgment at a military penitentiary. Indonesia's current military justice system adopts a system in which military court has jurisdiction of general nature, i.e., authorized to adjudicate general and civil offences in addition to military offences.

The continuing Demand for Reform has led the Martial Court to limit its jurisdiction given the reason that it is part of the quality improvement of democracy and politics of the people, not immediately eliminate the need of strong and independent Martial Court. Martial Court is necessary as a mechanism of internal control over the offenses by TNI soldiers. On the other side, the Indonesian military as a institution which has been the backbone of the Unitary State of the Republic of Indonesia, must continue to uphold the Fairness by placing general 


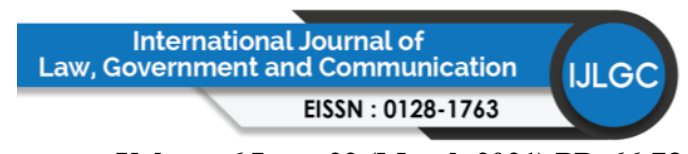

Volume 6 Issue 22 (March 2021) PP. 66-73

DOI 10.35631/IJLGC.622006

criminal offenses by TNI members as personal responsibility. Therefore, TNI institution will grow stronger, cleaner and authoritative.

TNI soldiers form part of the law society with the role in promoting the creation of legal culture in its body, not a group outside the society, not an independent caste of people above the society. TNI is not more than part of the society with particular obligations. The message was conveyed by General Soedirman in Yogyakarta on 1 January 1946. In terms of the role of TNI as the frontline in anticipating the threat and danger to the integrity of the nation, strength and solidness of TNI is demanded. Criminal act by TNI soldiers would weaken TNI, hence a facility is available in the form of Martial Court for law enforcement, besides its role as a part of personnel and organizational development of TNI. Martial Court, is a court separate and distinguished from General Court, as defined in the Explanation to Article 10 of Law No. 14 of 1970, Standard Rules of Judicial Authority which states that Religious, military and State Administrative Court are special courts, examining and judging specific cases or certain groups of people. Meanwhile General Court is the court for people in general on civil or criminal cases. The existence of military is for certain group of people, not general people, and Martial Court, is still maintained to try criminal cases committed by military member.

Indonesia's Military Court is principally a specific community which has its own culture separate from the culture of the public in general, for example, the culture that each subordinate must respect his/her superior and legal sanctions will be imposed on subordinates who do not respect their superiors (Tiarsen Buaton, 2016). Another example is the culture that they are willing to die for the state and the country. There is also a doctrine which says to kill or not to be killed and this is true because they are trained for this. Principally, legal culture within the military circle should be seen from the everyday attitude of the members. Since it has its own culture, military has its own law, in addition to general laws. For the purpose of law enforcement within it circle, military court is required to enforce not only military law, but also general laws that apply also to military members. Law enforcement measure through military court is the last remedy (ultimum remidium) if disciplinary measures and disciplinary law enforcement taken by each Commander fail to cope with it.

So, military court is a means to maintain and promote military discipline so that each military member is always prepared to be deployed in any assignment at any time and place. Military justice exercises the authority of the judicial body within the armed force to enforce the law and justice, taking into account the administration of state defense. Article 7 of the Law Number 31 of 1997 states that development of the organization and procedures, administration and finance of the judicial bodies and judge advocate's offices are done by the Commander, such development being not reducing the judge's freedom to examine and decide cases.

The pattern of the military life is specific, subject to disciplines that are specifically set out in military disciplinary law, which can be understood only by military members, so it is necessary for the military justice function to be organized by military members. The military justice's position in the state justice system adopted by and applied in Indonesia in its current form can be explained in various laws. In one side, the 1945 Constitution determines that judicial authority an independent power separate from the government's intervention, and contains the principle of independent judiciary, which is a present and future universal 


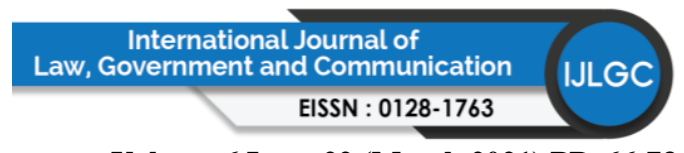

Volume 6 Issue 22 (March 2021) PP. 66-73

DOI 10.35631/IJLGC.622006

ideology. Military justice is a special judiciary with respect to the object and subject, i.e., certain class of people (TNI members or the equivalent). Further, Articles 1 and 2 of the KUHPM states that application of the Criminal Code (KUHP) to the KUHPM and to those who are subject to military justice and commit an offence and not set out in the KUHPM, the KUHP should apply. Quoting the theory put forth by Friedman (2009), stating that legal system components include legal culture, legal substance, and legal structure. Legal culture is the legal culture of the society; legal substance is legal material that is set out in laws and regulations; and legal structure is law enforcement agency. The relevance of the theory in relation to the existence of military justice is in line, where military members who commit a general offence will remain tried in the Military Court.

\section{Recommendations}

1. The Government of RI through Ministry of Law and Human Rights must continue to develop and maintain Martial Court system by amending and revising Law Number 31 of 1997 on Martial Court to keep pace with the progress of Democracy for the interest of National Defense

2. Commander in-chief of TNI through Legal Development of TNI in its function as the Legal Advisor for TNI based on the mechanism and hierarchy must revise the Martial Law relative to need of needs of TNI institution in the Martial Court system currently in force

\section{Conclusion}

In conclusion, Military Court Law is one of the mechanisms which is continuingly built and developed in the Military Criminal Justice system in Indonesia to try each TNI member who commits military and general offences. The existence of Military Court has been in accordance with the TNI organization requirements for state defense and security as viewed from legal Culture, Benefit, Certainty and Justice. In addition, Military Court is still effective, fair and realistic in making fair rulings based on the jurisdiction violated.

\section{References}

Amiroeddin Sjarif. (1983). Disiplin Militer dan Pembinaanya, Ghalia Indonesia: Jakarta.

Amiroeddin Sjarif. (1996). Hukum Disiplin Militer Indonesia, Rineka Cipta: Jakarta.

Barda Nawawi Arief. (2002). Kebijakan Hukum Pidana, PT. Citra Aditya Bakti: Bandung.

Dini Dewi Heniarti. (2017). Sistem Peradilan Militer di Indonesia: Tinjauan Teoritis, Praktis, Perbandingan Hukum \& Pembaruan Hukum Nasional, Refika Aditama, Bandung.

Eva Achjani Zufa, Indriyanto Seno Adji. (2011). Pergeseran Paradigma Pemidanaan, Lubuk Agung: Bandung

Friedman, L., M. (2009). Sistem Hukum Perspektif Ilmu Sosial The Legal System A Social Science Perspective, Nusa Media: Bandung.

Kamus Besar Bahasa Indonesia, 2012.

Kelsen, H. (2011). General Theory of Law and State, diterjemahkan oleh Rasisul Muttaqien, Nusa Media: Bandung.

Marcus Priyo Gunarto, Redefinisi Perbuatan Pidana pada Peradilan Militer, Makalah disampaikan pada Semiloka Implikasi Reposisi TNI-Polri di Bidang Hukum, FH UGM, tanggal 22 - 23 Nopember Yogyakarta

Masriani, Yulies Tiena. (2004). Pengantar Ilmu Hukum, Sinar Grafika: Jakarta.

Moch. Faisal Salam. (1994). Peradilan Militer di Indonesia, Mandar Maju: Bandung. 
Volume 6 Issue 22 (March 2021) PP. 66-73

DOI 10.35631/IJLGC.622006

R. Sianturi. (2011). Hukum Pidana Militer Indonesia: Jakarta.

Soerjono Soekanto \& Sri Mamudji. (2009). Penelitian Hukum Normatif Suatu Tinjauan Singkat, Cetakan ke 11. Raja Grafindo Persada: Jakarta.

Soerjono Soekanto. (2005). Faktor-faktor yang Mempengaruhi Penegakkan Hukum, PT. Raja Grafindo Persada: Jakarta.

Tiarsen Buaton. (2016). Peradilan Militer di Indonesia di Bawah Kekuasaan Makamah Agung dalam Demi Keadilan. Antologi Hukum Pidana dan Sistem Peradilan Pidana, Editor Jufrina Rizal, Suhariyono AR Pustaka Kemang: Jakarta.

Zainudin Ali. (2008). Sosiologi Hukum, Sinar Grafika: Jakarta. 